\title{
Memórias a caminho da justiça: Juicio por la Verdad de Mar del Plata
}

Marina de Lira Rocha ${ }^{1}$

Resenha recebida em: 27 de novembro de 2014

Resenha aprovada para publicação em: 7 de abril de 2015

ROMANIN, Enrique Andriotti. Memorias en conflicto: el movimiento de Derechos Humanos y la construcción del Juicio por la Verdad de Mar del Plata. Mar del Plata: Editorial de la Universidad Nacional de Mar del Plata (EUDEM), 2013. 263 p.

Somos muito acostumados a ler sobre a ditadura Argentina (1976-1983) e as questões de quebra dos direitos humanos nesse período, a partir de uma perspectiva já consolidada e de seus desdobramentos envolvidos com a justiça penal. ${ }^{2}$ Acontece que, para aqueles que adentram a temática, é sabido que todo o contexto atual é consequência de um processo, de um desenvolvimento de demandas sociais, que foram obtendo espaços e vozes para construir suas memórias e responsabilidades.

O livro de Enrique Andriotti Romanin ${ }^{3}$ aborda, desde um olhar regional, parte desse crescimento de possibilidades dos direitos humanos no país. O autor trabalha com a cidade de Mar del Plata, "a cidade feliz" dos anos 1960, apreciada por ser o balneário da classe média argentina. No entanto, se - como afirma Ludmila Catela - o interior argentino, durante a ditadura, é associado a seus "casos" (CATELA, 2001), Mar del Plata também é conhecida pela Noche de las Corbatas, episódio no qual foram sequestrados seis advogados da cidade, em julho de 1977. Este é, pois, um livro

\footnotetext{
1 Doutoranda do Programa de Pós-Graduação em História Social da Universidade de São Paulo. Bolsista da Coordenação de Aperfeiçoamento de Pessoal de Nível Superior. Email: mmlrocha@hotmail.com

${ }^{2}$ Neste sentido, a respeito do Nunca Más argentino temos pesquisas como a de Crenzel (2008); sobre os julgamentos de crimes de Lesa Humanidade no país há a obra coletiva organizada pelo Centro de Estudios Legales y Sociales (2011); sobre Políticas de Memória com premissas dos julgamentos já consolidadas vê-se o livro de Bauer (2014), etc.

${ }^{3}$ Professor no Departamento de Sociologia da Universidad Nacional de Mar del Plata (UNMP) e pesquisador assistente do Consejo Nacional de Investigaciones Científicas y Tecnicas (CONICET).
}

\section{CANPHLAC}

Revista Eletrônica da ANPHLAC, ISSN 1679-1061, №. 18, p. 305-311, jan./jul. 2015. http://revista.anphlac.org.br/ 
sobre os direitos humanos em um ambiente delimitado regional e contextualmente, mas que se amplia cruzando a fronteira para o nacional e internacional.

Em anos considerados complexos para as atividades das organizações de direitos humanos - em finais dos anos 1980 e início dos anos 1990 foram marcados pelas leis de Punto Final e Obediencia Debida e pelos indultos concedidos aos militares na presidência de Carlos Menem $^{4}$-, Romanin trata de estratégias. De estratégias que, não podendo alcançar a justiça penal e considerar juridicamente responsabilidades, dirigem-se para a obtenção da verdade e justiça, mediante juízos chamados Juicios por la Verdad. Estes colocam-se no lugar de recopilar informação, buscar crianças apropriadas e explorar as diferentes vias jurídicas que fossem contrárias às leis de impunidade, inclusive usando-se possibilidades internacionais (com o sentido de justiça universal ${ }^{5}$ e do efeito boomerang $^{6}$ ).

O grande impulso que receberam essas novas estratégias do contexto, que as colocou novamente em pauta na agenda pública, foi dado tanto pelas declarações de Adolfo Scilingo $^{7}$, em 1995, no qual reconheceu publicamente torturas, campos de detenção e Vuelos de la Muerte, quanto nas comemorações e mobilizações pelos 20 anos do golpe de Estado, no ano seguinte. Familiares e membros de organismos de direitos humanos iniciaram um retorno ao poder judicial, ora respaldados por instâncias internacionais - como em casos colocados na Comissão Interamericana de Direitos Humanos (CIDH) -, ora respaldados pela Justiça de França e Espanha, apelando simbolicamente à justiça pela verdade sobre os crimes da ditadura. Estes atos, segundo Romanin, foram protestos éticos para a instituição pela verdade, contudo também, desejos velados de conseguir castigo aos violadores.

\footnotetext{
${ }^{4}$ Nesse período, duas imagens me surgem sobre o momento que vivia o país: a imensa marcha com quase 200 mil manifestantes, no início de setembro de 1989, aos gritos de "iNo!” para os indultos e o discurso no qual Menem os proclamou, sugerindo com estes a reconciliação e pacificação - "Por eso, esa mañana, en hora muy buena y muy temprana, he firmado los decretos, que llevan los números 1002, 1004, y 1005, donde indulto a muchos militares y muchos civiles para que empecemos a reconstruir la Patria en paz, en libertad y justicia."

${ }^{5}$ Impacto simbólico que causava os processos exteriores sobre crimes contra os direitos humanos.

${ }^{6}$ Retroalimentação entre os processos, no caso, em nível internacional, e as tarefas desenvolvidas pelas organizações de direitos humanos no país, principalmente no que tangia a recolhimentos de provas e testemunhos.

${ }^{7}$ Ex-capitão de Corveta argentino que desempenhou funções na Escuela de Mecánica de la Armada (ESMA). (VERBITSKY, 1995)
}

\section{CANPHLAC}

Revista Eletrônica da ANPHLAC, ISSN 1679-1061, №. 18, p. 305-311, jan./jul. 2015. http://revista.anphlac.org.br/ 
Neste sentido, o primeiro dos chamados Juicios por la Verdad começou em 1998, na cidade de La Plata. Mundialmente inéditos, esses juízos buscavam saber as circunstâncias, os modos, os lugares, as datas, e as pessoas envolvidas em cada violação dos direitos humanos (VERBITSKY, 2000). Ao longo do tempo, foram-se espalhando por todo o país - Bahía Blanca, Buenos Aires, Mendonza, Rosario, Córdoba, Salta, Misiones, Jujuy e Mar del Plata. Para além das dimensões políticas e de estratégias jurídicas dos peticionários desses casos apresentados à Justiça, os juízos pela verdade significaram uma exposição social do Terrorismo de Estado, que suavizou o sentimento de injustiça compartilhado pelos familiares e sobreviventes, vítimas da violência ditatorial.

Apesar de Mar del Plata já ter sido considerada um estudo de caso específico durante os trabalhos da Comisión Nacional sobre la Desaparición de Personas (CONADEP), na década de 1980, e deter informações sobre a violência estatal e suas vítimas na cidade, a maioria dos familiares de desaparecidos e integrantes de organismos de direitos humanos manifestaram o interesse de desenvolver essa modalidade de juízo. Entendiam que, desta forma, poderiam demandar uma verdade simbólica, no que implica conhecer os feitos repressivos, e uma verdade material, saber o destino final dos desaparecidos.

Diante desta contradição entre impunidade e verdade, as organizações de direitos humanos mardelplatenses se reuniram na Comisión del Juicio por la Verdad (CJV) com intuito de as estabelecer e proceder. Desta forma, conseguiram angariar apoio social e político em torno do Jucio por la Verdad, debater a noção de verdade e de vítimas, constituir procedimentos de audiências públicas e abertas à comunidade e decidir quais testemunhos gostariam de recolher (entre eles, os violadores também participariam) $)^{8}$.

No desenrolar do texto, analisando diversos documentos, como testemunhos dos juízos, publicações sobre eles, jornais e revistas da época, Enrique Romanin nos apresenta uma série de inovações que este Juicio por la Verdad, em particular, instituiu em relação aos demais juízos pelo país e às próprias estratégias das

\footnotetext{
${ }^{8}$ Deve-se lembrar que alguns deles foram presos por se recusarem a depor nos Juicios por la Verdad, e o autor aborda casos ocorridos em Mar del Plata.
}

\section{GANPHLAC}

Revista Eletrônica da ANPHLAC, ISSN 1679-1061, №. 18, p. 305-311, jan./jul. 2015.

http://revista.anphlac.org.br/ 
organizações de direitos humanos. Uma das mais interessantes é a expansão interpretativa dos envolvidos sobre a violência de Estado. Utilizando-se das experiências dentro da cidade e do surgimento da Concentración Nacional Universitaria (CNU) - fundada em 1968, com ideais nacionalistas, conservadores, católicos e medievalistas -, os envolvidos no Juicio por la Verdad em Mar del Plata demandaram investigações sobre as atividades dessa organização anteriores ao golpe e sobre sua associação com a Triple $A^{9}$. Essa espécie de "ampliação" sobre os violadores dos direitos humanos abriu outra brecha para investigação da verdade, radicada também em civis que participaram do aparato repressivo e convieram com a violência estatal.

Outro importante aporte do juízo mardelplatense, proposto pelo autor, foi sua visão de objetivo final, juridicamente limitado pela impunidade, estava sempre voltado a conseguir provas para, ao fim, chegar-se ao castigo. Neste sentido, as palavras reproduzidas no texto de uma das componentes da CJV sintetizam a ideia: "el objetivo máximo es el de obtener la verdad y el juicio y el castigo a los culpables; el objetivo que hoy nos permite nuestra legislación es investigar la verdad que no es poca cosa" (ROMANIN, 2013, p. 121). Logo, os testemunhos e as provas, no Juicio por la Verdad, eram recolhidos não apenas para conhecer a verdade sobre o Terrorismo de Estado na cidade, mas também para compor processos, quando se chegasse, enfim, à anulação das leis de impunidade.

No texto, alguns conceitos utilizados são essenciais para pensarmos o crescimento dos espaços e das demandas de indivíduos relacionados às questões dos direitos humanos. Não os apontando em ordem de revelação, mas na centralidade que me pareceu nesta análise, o primeiro seria a ideia de "empreendedores da memória". $\mathrm{O}$ autor explora de diferentes maneiras essas dimensões de ações e esses personagens coletivos, que intentam, em uma esfera pública, dar legitimidade a suas versões de memória (JELIN, 2002). Depois, o desenvolvimento dos "cenários de memória" aparece como sendo espaços em que se apresentam relatos "sobre a verdade do

\footnotetext{
${ }^{9}$ A Alianza Anticomunista Argentina (Triple A) foi um grupo clandestino, formado majoritariamente por membros e ex-membros da polícia aliados à direita peronista, que realizava ações de sequestros e assassinatos, cujas vítimas eram peronistas de esquerda, líderes sociais, políticos da oposição, sindicalistas, intelectuais, dirigentes juvenis, jornalistas, advogados, artistas, etc. (JANZEN, 1986).
}

\section{GANPHLAC}

Revista Eletrônica da ANPHLAC, ISSN 1679-1061, №. 18, p. 305-311, jan./jul. 2015. http://revista.anphlac.org.br/ 
passado" e em que se faz escutá-los (FELD, 2002). Desta forma, o autor dá voz aos personagens na institucionalização dos juízos e aborda os lugares nos quais eles ocorrem.

Contudo, o objeto de estudo desse livro possui um final. Muitos dos Juicios por la Verdad terminaram com a derrogação das leis de impunidade, assinada pelo presidente Néstor Kirchner. O caso de Mar del Plata foi distinto, uma vez que as organizações decidiram manter este tipo de juízo, em conjunto com os novos processos que se abririam com fins de responsabilização. Então, Romanin, de alguma forma, procura apontar os dilemas vivenciados pelas organizações de direitos humanos em todo o país, com um governo que buscava legitimidade utilizando-se de suas consignas. Esse novo contexto as obrigaria a repensar estratégias políticas e vinculações com o Estado nacional.

Em Mar del Plata, decidiu-se continuar a busca por informações. Logo, persistiu-se em recolher testemunhos e sinalizar Centros Clandestinos de Detenção (CCD) por toda a cidade. Em fins de abril de 2008, no entanto, depois de sete anos e de muitos conflitos políticos e jurídicos, realizou-se ali a última audiência do Juicio por la Verdad. Seu fim ocorreu sem um ponto final. Ninguém se encarregaria de dizer que estava sendo realizada a última audiência, a qual aconteceu com apenas o recolhimento do último depoimento deste juízo, que deixou 250 testemunhos, inúmeras provas documentais, algumas detenções e instruções para os juízos penais em marcha.

Talvez por toda a obra, fruto de uma extensa pesquisa de doutorado no Programa de Ciências Sociais da Universidad Nacional de General Sarmiento (UNGS), o leitor tenha o desejo de aprofundar o conhecimento sobre o espaço público dos Juicios por la Verdad, sobre as recepções dialógicas deles. Se esta modalidade de juízo mardelplatense foi produzida a partir de audiências abertas à comunidade (um "cenário de memória", como descreve o próprio autor), onde está o público no texto? Não podemos negar que o autor explora de alguma forma o tema, exibindo-nos a falta de interesse da imprensa local em abordar tais trâmites, assim como o interesse público manifestado nas audiências cheias (que, ao longo dos processos, vão se esvaziando) para assistir e participar politicamente de tal façanha histórica. Mas fica

\section{GANPHLAC}

Revista Eletrônica da ANPHLAC, ISSN 1679-1061, №. 18, p. 305-311, jan./jul. 2015.

http://revista.anphlac.org.br/ 
sempre o desejo de saber um pouco mais. E, quiçá, esta seja uma das melhores características do estudo: não se fecha em si, provoca o leitor neste objeto escassamente trabalhado e se abre para possibilidades.

Desta forma, o livro de Romanin é um ótimo texto sobre a constituição dos Juicios por la Verdad em Mar del Plata e seus desdobramentos ao longo do tempo, em termos regionais, nacionais e internacionais. Coloca-nos diante de uma série de questões e resoluções propostas pelas organizações de direitos humanos, suas lutas perante um contexto desfavorável e como conseguiram ampliar seus espaços nas Políticas de Memória do Estado. Como abriram portas e percorreram caminhos.

\section{GANPHLAC}

Revista Eletrônica da ANPHLAC, ISSN 1679-1061, №. 18, p. 305-311, jan./jul. 2015. http://revista.anphlac.org.br/ 


\section{Bibliografia}

BAUER, Caroline Silveira. Brasil e Argentina: ditaduras, desaparecimentos e Políticas de Memória. Porto Alegre: Medianiz, 2014.

CATELA, Ludmila da Silva. Situação-limite e memória. A reconstrução do mundo dos familiares de desaparecidos da Argentina. São Paulo: Hucitec, 2001.

CENTRO DE ESTUDIOS LEGALES Y SOCIALES (Org.). Hacer justicia: nuevos debates sobre el juzgamiento de crímenes de lesa humanidade en Argentina. Buenos Aires: Siglo XXI, 2011.

CRENZEL, Emilio. La Historia política del Nunca Más: la memoria de las desapariciones en la Argentina. Buenos Aires: Siglo XXI, 2008.

FELD, Claudia. Del estrado a la pantalla: las imágenes del juicio a los ex comandantes en Argentina. Madrid: Siglo XXI, 2002.

JANZEN, Ignacio González. La Triple A. Buenos Aires: Editorial Contrapunto, 1986.

JELIN, Elizabeth. Los trabajos de la memoria. Buenos Aires: Siglo XXI, 2002.

VERBITSKY, Horacio. El vuelo. Buenos Aires: Editorial Planeta, 1995.

. El camino de la verdad. Revista Puentes, La Plata, No 1, Agosto de 2000.

\section{GANPHLAC}

Revista Eletrônica da ANPHLAC, ISSN 1679-1061, №. 18, p. 305-311, jan./jul. 2015.

http://revista.anphlac.org.br/ 